\title{
Marinobacter excellens sp. nov., isolated from sediments of the Sea of Japan
}

\author{
Nataliya M. Gorshkova, ${ }^{1}$ Elena P. Ivanova, ${ }^{2}$ Alexandr F. Sergeev, ${ }^{3}$ \\ Natalia V. Zhukova, ${ }^{4}$ Yulia Alexeeva, ${ }^{2,3}$ Jonathan P. Wright, ${ }^{2}$ \\ Dan V. Nicolau, ${ }^{2}$ Valery V. Mikhailov ${ }^{1}$ and Richard Christen ${ }^{5}$
}

Correspondence Elena P. Ivanova eivanova@swin.edu.au

\author{
${ }^{1}$ Pacific Institute of Bioorganic Chemistry, Far-Eastern Branch of the Russian Academy of \\ Scences, 690022 Vladivostok, Pr. 100 Let Vladivostoku 159, Russia \\ ${ }^{2}$ Industrial Research Institute, Swinburne University of Technology, PO Box 218, Hawthorn, \\ Vic 3122, Australia \\ ${ }^{3}$ Pacific Oceanological Institute, Far-Eastern Branch of the Russian Academy of Sciences, \\ Baltiiskaya Str. 43, 690017, Vladivostok, Russia \\ ${ }^{4}$ Institute of Marine Biology, Far-Eastern Branch of the Russian Academy of Sciences, \\ 690038, Palchevskogo Str. 17, Vladivostok, Russia \\ ${ }^{5} U M R 6543$ CNRS, Université de Nice Sophia Antipolis, Centre de Biochimie, Parc Valrose, \\ F06108 Nice cedex 2, France
}

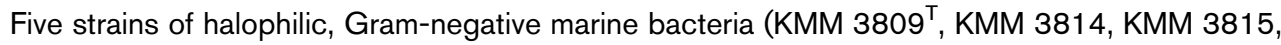
KMM 3817 and KMM 3818) were isolated from sediments collected from Chazhma Bay, Sea of Japan. Phylogenetic 16S rRNA gene sequence-based analysis placed these bacteria in a clade within the genus Marinobacter in the $\gamma$-Proteobacteria. KMM $3809^{\top}$ showed highest $16 \mathrm{~S}$ rRNA gene sequence similarity of $97 \cdot 3 \%$ to Marinobacter litoralis and $96 \cdot 9 \%$ to Marinobacter hydrocarbonoclasticus and Marinobacter aquaeolei. DNA-DNA hybridization between the five isolates was at the conspecific level (94-96\%) and that among the closest phylogenetic neighbours ranged from $45 \cdot 0$ to $62.5 \%$. The new organisms were susceptible to polymyxin. Predominant fatty acids were $C_{16: 0}, C_{16: 1} \omega 9 c, C_{16: 1} \omega 7 c$ and $C_{18: 1} \omega 9 c$. Phylogenetic evidence, along with phenotypic and genotypic characteristics, showed that the bacteria constituted a novel species of the genus Marinobacter. The name Marinobacter excellens sp. nov. is proposed for

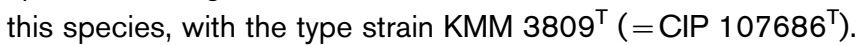

The genus Marinobacter, with the type species Marinobacter hydrocarbonoclasticus, was created in 1992 to accommodate Gram-negative, moderately halophilic, aerobic $\gamma$-Proteobacteria that used a variety of hydrocarbons as the sole source of carbon and energy (Gauthier et al., 1992). One more species, Marinobacter aquaeolei, was described recently (Nguyen et al., 1999) and the misclassified species [Pseudomonas] nautica was assigned to M. hydrocarbonoclasticus (Spröer et al., 1998). This group of marine Proteobacteria comprises efficient biodegraders of hydrocarbons, polycyclic aromatic carbons and acyclic isoprenoid

Abbreviations: AFM, atomic force microscopy; DPG, diphosphatidylglycerol; ML, maximum-likelihood; MP, maximum-parsimony; NJ, neighbourjoining; PE, phosphatidylethanolamine; PG, phosphatidylglycerol.

The GenBank/EMBL/DDBJ accession number for the 16S rRNA gene sequence of strain $\mathrm{KMM} 3809^{\top}$ is $\mathrm{AY} 180101$.

A table showing cellular fatty acid composition of Marinobacter species and further AFM images of cells of $M$. excellens are available as supplementary material in IJSEM Online. compounds (Rontani et al., 1999; Hedlund et al., 2001; Melcher et al., 2002). Intensive studies of Marinobacter spp. metabolites of sufficient structural specificity suggest that they may have an important role as biological markers for microbial degradation in the aquatic environment.

In this study, we present the characterization of novel bacteria of the genus Marinobacter that were isolated from sediments collected in Chazhma Bay, Sea of Japan. This work was part of the taxonomic investigation of free-living marine bacteria dwelling in the Bay, sediments of which were contaminated by radionuclides (Ivanova et al., 2002). Sediment samples were collected in 2001 from a depth of $0.5 \mathrm{~m}$ (salinity, $32 \%$; temperature, $12{ }^{\circ} \mathrm{C}$ ) at Chazhma Bay, Sea of Japan. Bacteria were isolated by plating $0 \cdot 1 \mathrm{ml}$ of a suspension of $1 \mathrm{~g}$ sediment in $10 \mathrm{ml}$ sterilized natural sea water onto marine 2216 agar plates (Difco) or plates with medium B that contained $0 \cdot 2 \%(\mathrm{w} / \mathrm{v})$ Bacto peptone (Difco), $0 \cdot 2 \%(\mathrm{w} / \mathrm{v})$ casein hydrolysate (Merck), $0 \cdot 2 \%$ $(\mathrm{w} / \mathrm{v})$ Bacto yeast extract (Difco), $0 \cdot 1 \%(\mathrm{w} / \mathrm{v})$ glucose, 
$0.02 \%(\mathrm{w} / \mathrm{v}) \mathrm{KH}_{2} \mathrm{PO}_{4}, 0.005 \%(\mathrm{w} / \mathrm{v}) \mathrm{MgSO}_{4} \cdot 7 \mathrm{H}_{2} \mathrm{O}, 1 \cdot 5 \%$ $(\mathrm{w} / \mathrm{v})$ Bacto agar (Difco), $50 \%(\mathrm{v} / \mathrm{v})$ natural sea water and $50 \%(\mathrm{v} / \mathrm{v})$ distilled water at $\mathrm{pH} 7 \cdot 8$. Plates were incubated aerobically at room temperature (approx. $22-25^{\circ} \mathrm{C}$ ) for 5,7 or 10 days. Strains were stored at $-80^{\circ} \mathrm{C}$ in marine 2216 broth (Difco) supplemented with $20 \%$ (v/v) glycerol. In total, 145 viable bacterial strains have been recovered from sea water and sediment samples. During isolation studies, bacteria of different taxonomic groups, including Shewanella, Halomonas, Pseudoalteromonas and Kocuria, have been isolated (Ivanova et al., 2002). From this collection, several bacterial strains with Marinobacter-like phenotypes were identified initially and studied further in detail.

Unless indicated otherwise, phenotypic characteristics were studied by using standard procedures (Baumann et al., 1972; Smibert \& Krieg, 1994) as described previously (Ivanova et al., 1996, 1998). Tests for utilization of various organic substrates as sole carbon sources at a concentration of $0 \cdot 1 \%(\mathrm{w} / \mathrm{v})$ were performed in $10 \mathrm{ml}$ liquid $\mathrm{BM}$ medium (Baumann et al., 1972). Ability to oxidize organic substrates was investigated by using Biolog GN plates as described previously (Ivanova et al., 1998). The following physiological and biochemical properties were examined: oxidation/ fermentation of glucose, denitrification, catalase and oxidase activities, gelatin liquefaction, sodium requirement [at $0,1,3,6,8,10,12,15$ and $20 \%(\mathrm{w} / \mathrm{v}) \mathrm{NaCl}$, production of indole and $\mathrm{H}_{2} \mathrm{~S}$ and ability to hydrolyse starch, Tween85 and casein. Haemolytic activity of the strains was detected on blood agar $\left(1^{-1}\right.$ : trypticase soy agar, $40 \mathrm{~g}$; mouse blood, $50 \mathrm{ml}$; water, $950 \mathrm{ml}$ ). Cytotoxic and antibacterial activities were assessed by the agar-diffusion assay, based on methods described elsewhere (Barry, 1980; Sasaki et al., 1985). Cultures $(0 \cdot 1 \mathrm{ml})$ of indicator test strains were spread on tryptic soy agar plates in which circular wells (diameter, $10 \mathrm{~mm}$ ) had been cut. Areas of inhibited bacterial growth were measured after incubation for $48 \mathrm{~h}$ at $28^{\circ} \mathrm{C}$. Zones of inhibited growth of the indicator strains surrounding the wells were observed, mean diameters were measured and $10 \mathrm{~mm}$ was subtracted to represent the diameter of the well. Antimicrobial activities were tested against Staphylococcus aureus CIP 103594, Escherichia coli ATCC 25290, Proteus vulgaris NBRC $3851^{\mathrm{T}}$, Enterococcus faecium CIP 104105, Bacillus subtilis ATCC $6051^{\mathrm{T}}$ and yeast Candida albicans KMM 455. Atomic force microscopy (AFM) was employed to characterize the morphology of the cells, by using a TopoMetrix Explorer (model no. 440011; ThermoMicroscopes) in the non-contact mode, with either a $2 \mu \mathrm{m}$ liquid scanner $(0.8 \mu \mathrm{m} z$-range; model no. 5270-00) or a $100 \mu \mathrm{m}$ liquid scanner ( $10 \mu \mathrm{m} \mathrm{z}$-range; model no. 5180-00). Silicon cantilevers with a spring constant of $42 \mathrm{~N} \mathrm{~m}^{-1}$ and resonant frequency of $320 \mathrm{kHz}$ (model no. 1650.00) were used; all imaging was performed in ethanol. All samples were prepared on freshly cleaved mica. Morphological and physiological properties are shown in Fig. 1, Table 1 and Supplementary Table A (available in IJSEM Online) and given in the species description.

The 16S rRNA gene was amplified and sequenced by MIDI Laboratories, Newark, USA. Briefly, primers used for amplification corresponded to E. coli positions 5 and 1540 . Amplification products were purified by using Microcon 100 (Millipore) molecular mass cut-off membranes and checked for quality and quantity on an agarose gel. Cycle sequencing of $16 \mathrm{~S}$ rRNA gene amplification products was carried out by using AmpliTaq ES DNA polymerase and rhodamine dye terminators (Applied Biosystems). Samples were electrophoresed on an ABI Prism 377 DNA sequencer. The new 16S rRNA gene sequence was added and aligned by reference to a database of more than 60000 already aligned sequences. Automatic alignments were first obtained by using PCaligne, a program designed specifically for that purpose (Abdeddaïm, 1997). Related sequences were selected according to BLAST queries against the latest release of the 'Bacteria' division of GenBank. The 100 most closely related sequences were selected and alignments were refined manually by using SeaView (Galtier et al., 1996). (a)

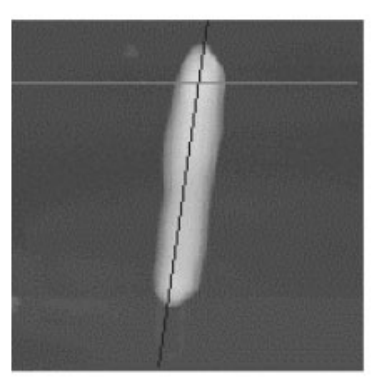

(b)

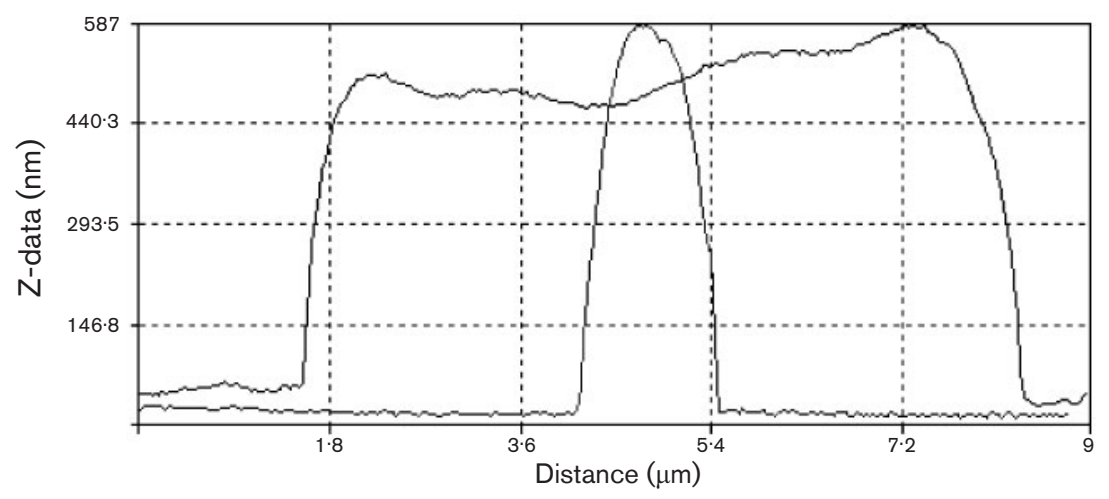

Fig. 1. Dimensional AFM deflection image showing (a) a cell of $M$. excellens $K M M 3809^{\top}$ grown for 24 h; (b) line profile of the cell, showing length (vertical line) and width (horizontal line). 
Table 1. Characteristics that differentiate $M$. excellens from phylogenetically related species

Taxa: 1, M. excellens KMM 3809 ${ }^{\mathrm{T}}$; 2, M. hydrocarbonoclasticus; 3, M. aquaeolei. All strains are straight rod-shaped organisms, are oxidase-positive, exhibit lipase, grow in $15 \% \mathrm{NaCl}$, do not hydrolyse gelatin, casein or chitin, are negative for haemolysis and are susceptible to polymyxin. W, Weakly positive. Data are from this study, Gauthier et al. (1992) and Nguyen et al. (1999).

\begin{tabular}{|lccc|}
\hline Characteristic & $\mathbf{1}$ & $\mathbf{2}$ & $\mathbf{3}$ \\
\hline DNA G+C content $(\mathrm{mol} \%)$ & $56 \cdot 0$ & $52 \cdot 7$ & $55 \cdot 7$ \\
Optimal growth temperature $\left({ }^{\circ} \mathrm{C}\right)$ & 28 & 32 & 30 \\
Growth at/in: & & & \\
$10^{\circ} \mathrm{C}$ & + & + & - \\
$45^{\circ} \mathrm{C}$ & - & + & + \\
$0 \% \mathrm{NaCl}$ & - & - & + \\
Catalase & $\mathrm{W}$ & + & + \\
Denitrification & + & + & - \\
Production of: & & & \\
Amylase & + & - & - \\
Alginase & - & + & - \\
Utilization of: & & & \\
D-Glucose & - & - & - \\
D-Galactose & $-\left(1^{\star}\right)$ & - & - \\
DL-Lactate & - & + & + \\
Succinate & - & + & + \\
Citrate & - & + & + \\
Susceptibility to: & & & \\
Gentamicin & - & - & + \\
Kanamycin & - & - & + \\
Neomycin & & & + \\
\hline
\end{tabular}

${ }^{\star}$ No. strains tested that are positive.

Phylogenetic trees were constructed according to three different methods: BIONJ as described by Gascuel (1997), maximum-likelihood with the 'global' option (ML) and maximum-parsimony (MP), both from PHYLIP (Phylogeny Inference Package, version 3.573c; distributed by J. Felsenstein, Department of Genetics, UW, Seattle, WA, USA). For the neighbour-joining (NJ) analysis, a distance matrix was calculated according to the Kimura twoparameter correction. Bootstraps were done by using 1000 replications and the BIONJ and Kimura two-parameter corrections. Phylogenetic trees were drawn by using NJPLOT (Perrière \& Gouy, 1996). Preliminary phylogenetic analyses were done by using the most conserved parts of the sequence, which were not likely to show too much homoplasy. These analyses, as well as a table sorting available sequences according to decreasing similarity, allowed us to select 13 sequences for the final analysis shown in this paper. Domains used to construct the final phylogenetic trees (positions 88-1469 of KMM $3809^{\mathrm{T}}$ ) were regions of the small-subunit rRNA gene sequences that were available for all sequences and excluded positions

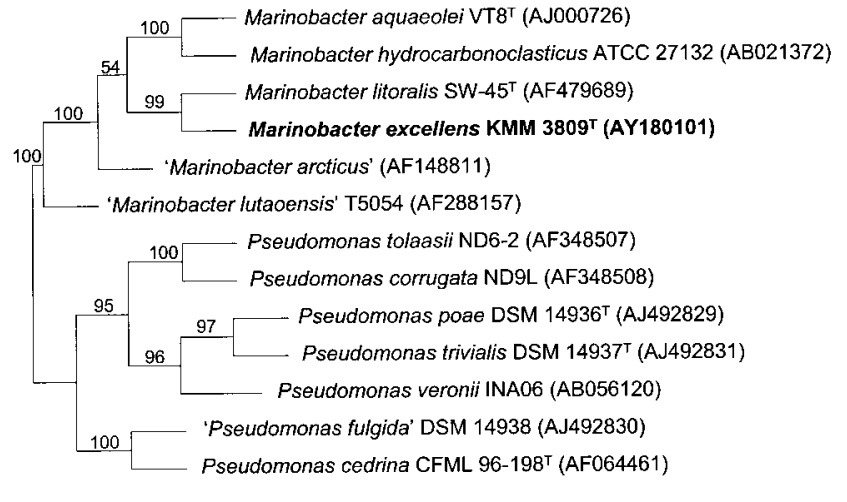

Fig. 2. Phylogenetic position of $M$. excellens according to $16 \mathrm{~S}$ rRNA gene sequence analysis. The topology shown was obtained by using the BIONJ algorithm and 1000 bootstrap replications with the Kimura two-parameter distance correction. Bootstrap values are indicated only for branches that were also retrieved by MP and ML $(P<0.01)$; these branches should be considered as the only robust clusters identified by this analysis.

that were likely to show homoplasy or notoriously difficult to sequence, i.e. the $5^{\prime}$ end of the sequences.

16S rRNA gene sequence analyses revealed that strain $\mathrm{KMM} 3809^{\mathrm{T}}$ is a member of the $\gamma$-Proteobacteria and, more precisely, that it is included in the clade formed by the genus Marinobacter (Fig. 2). The topology of the phylogenetic tree shown in Fig. 2 is that of the bootstrap analysis, as it has been demonstrated that this topology is often better than that of a simple NJ analysis (Gascuel, 1997). As a result, there is no distance bar in this tree; note also that the distance bar should be considered with caution in a tree, as it represents distances calculated after corrections (transversions being accounted for more than transitions) and branch-lengths do not represent the real number of differences between the sequences themselves. Bootstrap numbers are indicated only for branches that were also retrieved in the ML and MP trees (consensus tree). 16S rRNA gene sequence similarities with other available sequences were calculated by parsing the result of a BLAST analysis of KMM $3809^{\mathrm{T}}$ on the 'Bacteria' division of GenBank (at 25 November 2002), with the options 'no filter' and $\mathrm{W}=7$. The sequence of strain $\mathrm{KMM} 3809^{\mathrm{T}}$ had $97 \cdot 3 \%$ or less similarity to its nearest phylogenetic relatives, i.e. M. hydrocarbonoclasticus, M. aquaeolei and M. litoralis.

Results of the chemotaxonomic analysis are given in Supplementary Table A (available in IJSEM Online) and the species description. Isoprenoid quinones were extracted from lyophilized cells and analysed as described previously (Ivanova et al., 2003) according to Moule \& Wilkinson (1987). Lipids were extracted as described previously (Ivanova et al., 2000). TLC revealed that phosphatidylethanolamine (PE) and phosphatidylglycerol (PG) were the major phospholipids; the amount of PE ranged from $48 \cdot 1$ 
to $54 \cdot 8 \%$, whilst the amount of PG ranged from $29 \cdot 0$ to $38 \cdot 4 \%$. Diphosphatidylglycerol (DPG) was also detected, at $9 \cdot 9-19 \cdot 4 \%$. Fatty acid methyl esters were prepared as described by Svetashev et al. (1995). The resulting fatty acid methyl esters were analysed on a Shimadzu GC-14A gas chromatograph with a flame-ionization detector by using both a non-polar SPB-5 fused-silica column (30 $\mathrm{m} \times$ $0.25 \mathrm{~mm}$, i.d.) at $210^{\circ} \mathrm{C}$ and a polar Supelcowax- 10 fused-silica column $(30 \mathrm{~m} \times 0 \cdot 25 \mathrm{~mm}$, i.d. $)$ at $200^{\circ} \mathrm{C}$. The fatty acid composition of the five strains was similar (see Supplementary Table A in IJSEM Online). Three components, $\mathrm{C}_{16: 0}, \mathrm{C}_{16: 1} \omega 9 c$ and $\mathrm{C}_{18: 1} \omega 9 c$, accounted for $>70 \%$ of total fatty acids. Minor fatty acids included $\mathrm{C}_{12: 0}, \mathrm{C}_{14: 0}, \mathrm{C}_{15: 0}, \mathrm{C}_{17: 0}, \mathrm{C}_{18: 0}$ and $\mathrm{C}_{17: 1} \omega 8 \mathrm{c}$. In their main features, the fatty acid profiles were similar to those reported for Marinobacter species (Nguyen et al., 1999; Yoon et al., 2003). These authors found a relatively high proportion of hydroxy fatty acids (up to $10 \%$ ), whilst in our experiments, $\mathrm{C}_{12: 0} 3-\mathrm{OH}$ was detected in lower amounts (up to $0 \cdot 7 \%$ ). Such variation in the proportion of fatty acids was observed previously for other Proteobacteria (Huys et al., 1994; Ivanova et al., 2000) and can be explained by differing experimental conditions employed in different laboratories. In addition, a greater proportion of $C_{16: 1} \omega 9 c$ in the fatty acid profiles of the new isolates compared to those of other type strains and a number of differences in distribution of fatty acids present in minor amounts, i.e. accounting for $<5-7 \%$, namely $\mathrm{C}_{15: 0}, \mathrm{C}_{17: 0}$ and $\mathrm{C}_{17: 1} \omega 8 \mathrm{c}$, were also found. Notably, all bacteria of the genus Marinobacter exhibited an abundance of $\omega 9 \mathrm{c}$ isomers of the fatty acids $\mathrm{C}_{16: 1}$ and $\mathrm{C}_{18: 1}$, which is in agreement with results reported previously for type strains grown under different cultivation conditions (Nguyen et al., 1999; Yoon et al., 2003). We suggest that $\omega 9 c$ isomers of fatty acids $\mathrm{C}_{16: 1}$ and $\mathrm{C}_{18: 1}$ might be characteristic chemotaxonomic markers of the genus Marinobacter.

For genotypic characterization, DNA was isolated from the strains by following the method of Marmur (1961). The $\mathrm{G}+\mathrm{C}$ content of the DNA was determined by using the thermal denaturation method (Marmur \& Doty, 1962). The type strains of $M$. hydrocarbonoclasticus (ATCC $\left.49840^{\mathrm{T}}\right), M$. aquaeolei (ATCC $700491^{\mathrm{T}}$ ) and M. litoralis (KCCM $41591^{\mathrm{T}}$ ) were used for comparison of phenotypic properties and DNA-DNA hybridization experiments. All reference strains were cultured routinely on marine agar 2216 plates (Difco). DNA-DNA hybridization experiments were performed by using covalent attachment of the DNA in micro-wells, according to the method described by Christensen et al. (2000). Briefly, 300 ng DNA (400$700 \mathrm{bp}$ fragments) diluted in ice-cold 1-methylimidazole (Sigma), pH 7·0 and $25 \mu \mathrm{l} 40 \mathrm{mM}$ 1-ethyl-3-(3-dimethylaminopropyl) carbodiimide (EDC; Sigma) dissolved in sterilized Nanopure $\mathrm{H}_{2} \mathrm{O}\left(18 \cdot 2 \mathrm{M} \Omega \mathrm{cm}^{-1}\right)$ was added to each well of NucleoLink micro-well strips (Nalge Nunc International) to bind the DNA covalently to the NucleoLink surface. After incubation at $50^{\circ} \mathrm{C}$ for $18 \mathrm{~h}$ (without shaking), unbound DNA was washed continuously.
DNA labelling with photoactivated biotin, hybridization, detection and quantification were performed as described by Christensen et al. (2000). DNA-DNA hybridization data revealed a high level of DNA relatedness among KMM $3809^{\mathrm{T}}$, KMM 3814, KMM 3817 and KMM 3818, ranging from 93 to $96 \%$, which indicated that the strains belonged the same species (Wayne et al., 1987). As the phenotypic and chemotaxonomic characteristics of KMM 3815 were identical to those of KMM 3814, the former was excluded from DNA-DNA hybridization experiments. Genetic similarity of $\mathrm{KMM} 3809^{\mathrm{T}}$ with type strains of the genus Marinobacter, listed in Table 2, was $45-63 \%$. Based on the generally accepted criterion of the definition of genomic species (Wayne et al., 1987), strains KMM $3809^{\mathrm{T}}$, KMM 3814, KMM 3817 and KMM 3818 are assigned to the novel species.

Bacteria of the novel species have a number of distinct phenotypic features that allow them to be distinguished from other Marinobacter species (Table 2). For example, the newly isolated bacteria were not able to grow at temperatures higher than $41{ }^{\circ} \mathrm{C}$ and were able to denitrify and produce amylase. Notably, bacteria isolated from Chazhma Bay were only susceptible to one antibiotic (polymyxin) and remarkably resistant to the other 10 listed above; strain KMM 3814 was weakly susceptible to kanamycin. In contrast, $M$. aquaeolei was susceptible to gentamicin, kanamycin and neomycin as well as polymyxin and M. hydrocarbonoclasticus was susceptible to kanamycin.

\section{Description of Marinobacter excellens sp. nov.}

Marinobacter excellens (ex'cell.ens. L. masc. adj. excellens remarkable, exceptional).

The majority of cells are rod-shaped, with lengths and widths that vary from 1 to $8 \mu \mathrm{m}$ and from 0.6 to $1.4 \mu \mathrm{m}$, respectively (Fig. 1). They are motile, polarly flagellated, Gram-negative strains that are strictly aerobic heterotrophs. Anaerobic growth occurs by fermentation of D-glucose by

Table 2. DNA relatedness among tested strains

\begin{tabular}{|lcc|}
\hline Organism & $\begin{array}{c}\text { G+C content } \\
(\mathbf{m o l} \%)\end{array}$ & $\begin{array}{c}\text { Hybridization } \\
(\%)^{*}\end{array}$ \\
\hline M. excellens: & & \\
KMM 3809 & \\
KMM 3814 & $56 \cdot 0$ & 100 \\
KMM 3817 & $55 \cdot 7$ & $95 \cdot 8$ \\
KMM 3818 & $55 \cdot 0$ & $93 \cdot 8$ \\
M. hydrocarbonoclasticus ATCC & $55 \cdot 2$ & $93 \cdot 0$ \\
49840 & $52 \cdot 7$ & $62 \cdot 5$ \\
M. aquaeolei ATCC $700491^{\mathrm{T}}$ & $55 \cdot 7$ & \\
M. litoralis KCCM 41591 & $55 \cdot 0$ & $57 \cdot 0$ \\
& & \\
\hline
\end{tabular}

${ }^{\star}$ Values are hybridization (\%) with biotinylated DNA from M. excellens $\mathrm{KMM} 3809^{\mathrm{T}}$. 
anaerobic respiration of nitrate. No endospores are formed. Colonies on marine 2216 agar are circular, smooth, convex with an entire edge, transparent and $1-3 \mathrm{~mm}$ in diameter after 2 days incubation at room temperature (approx. $22-24^{\circ} \mathrm{C}$ ). Organic growth factors are not required. Growth occurs at $1-15 \% \mathrm{NaCl}$. No growth at $20 \% \mathrm{NaCl}$. Growth temperature ranges from 10 to $41{ }^{\circ} \mathrm{C}$, with optimum growth at $20-25^{\circ} \mathrm{C}$. No growth is detected at $45^{\circ} \mathrm{C}$. $\mathrm{pH}$ range for growth is $6 \cdot 0-10 \cdot 0$, with optimum growth at $\mathrm{pH} 7 \cdot 5$. Oxidase-positive and weakly positive for catalase. Amylase and lipase are hydrolysed, whereas gelatin, casein, chitin, agar, alginate and laminaran are not. Bacteria are non-haemolytic on mouse blood agar, non-cytotoxic, do not exhibit antimicrobial activity, are susceptible to polymyxin and resistant to ampicillin, benzylpenicillin, gentamicin, kanamycin, carbenicillin, neomycin, tetracycline, lyncomycin, oleandomycin and streptomycin. Positive for lipase and amylase, but negative for agarase, chitinase, caseinase and gelatinase; able to utilize a limited range of carbohydrates. Of the 95 carbon sources in the Biolog system, strain KMM $3809^{\mathrm{T}}$ utilized Tween-85, N-acetyl-Dglucosamine, D-fructose, maltose, D-mannitol, L-rhamnose, D-sorbitol, methyl pyruvate, monomethyl succinate, cisaconitic acid, D-galactonic acid lactone, $\alpha$-hydroxybutyric acid, $\gamma$-hydroxybutyric acid, succinic acid, L-histidine, L-leucine, L-phenylalanine, L-proline, L-pyroglutamic acid, D-serine, DL-carnitine, urocanic acid and 2-aminoethanol. Major respiratory lipoquinone is Q9; PE, PG and DPG are major phospholipids; cellular fatty acids are $\mathrm{C}_{16: 0}$, $\mathrm{C}_{16: 1} \omega 9 c, \mathrm{C}_{16: 1} \omega 7 c$ and $\mathrm{C}_{18: 1} \omega 9 c$. Organisms belong to the $\gamma$-Proteobacteria, based on $16 \mathrm{~S}$ rRNA gene sequences. DNA G $+\mathrm{C}$ content is $55 \cdot 0-56 \cdot 0 \mathrm{~mol} \%$.

The type strain is $\mathrm{KMM} 3809^{\mathrm{T}}\left(=\mathrm{CIP} 107686^{\mathrm{T}}\right)$. Isolated from sediments collected in Chazhma Bay, Sea of Japan.

\section{Acknowledgements}

The type strains of M. hydrocarbonoclasticus, M. aquaeolei and M. litoralis were generous gifts from Dr Stan-Lotter, Dr Park and Dr Yoon. This study was partially supported by the Russian Foundation for Basic Research (RFBR) grant no. 02-04-49517, grant no. 03-19 from the Ministry for Industry, Science and Technology of the Russian Federation, the Science Support Foundation RAS grant for talented researchers and grant no. 03-3-E-07-027 of the Far-Eastern Branch of the Russian Academy of Sciences.

\section{References}

Abdeddaïm, S. (1997). Fast and sound two-step algorithms for multiple alignment of nucleic sequences. Int J Artif Intell Tools 6, 179-192.

Barry, A. L. (1980). Procedures and theoretical considerations for testing antimicrobial agents in agar media. In Antibiotics in Laboratory Medicine, pp. 10-16. Edited by V. Lorian. Baltimore: Williams \& Wilkins.

Baumann, L., Baumann, P., Mandel, M. \& Allen, R. D. (1972). Taxonomy of aerobic marine eubacteria. J Bacteriol 110, 402-429.

Christensen, H., Angen, Ø., Mutters, R., Olsen, J. E. \& Bisgaard, M. (2000). DNA-DNA hybridization determined in micro-wells using covalent attachment of DNA. Int J Syst Evol Microbiol 50, 1095-1102.
Galtier, N., Gouy, M. \& Gautier, C. (1996). SeaView and Phylo_win, two graphic tools for sequence alignment and molecular phylogeny. Comput Applic Biosci 12, 543-548.

Gascuel, O. (1997). BIONJ: an improved version of the NJ algorithm based on a simple model of sequence data. Mol Biol Evol 14, 685-695.

Gauthier, M. J., Lafay, B., Christen, R., Fernandez, L., Acquaviva, M., Bonin, P. \& Bertrand, J.-C. (1992). Marinobacter hydrocarbonoclasticus gen. nov., sp. nov., a new, extremely halotolerant, hydrocarbondegrading marine bacterium. Int J Syst Bacteriol 42, 568-576.

Hedlund, B. P., Geiselbrecht, A. D. \& Staley, J. T. (2001). Marinobacter strain NCE312 has a Pseudomonas-like naphthalene dioxygenase. FEMS Microbiol Lett 201, 47-51.

Huys, G., Vancanneyt, M., Coopman, R., Janssen, P., Falsen, E., Altwegg, M. \& Kersters, K. (1994). Cellular fatty acid composition as a chemotaxonomic marker for the differentiation of phenospecies and hybridization groups in the genus Aeromonas. Int J Syst Bacteriol 44, 651-658.

Ivanova, E. P., Kiprianova, E. A., Mikhailov, V. V., Levanova, G. F., Garagulya, A. D., Gorshkova, N. M., Yumoto, N. \& Yoshikawa, S. (1996). Characterization and identification of marine Alteromonas nigrifaciens strains and emendation of the description. Int J Syst Bacteriol 46, 223-228.

Ivanova, E. P., Kiprianova, E. A., Mikhailov, V. V. \& 8 other authors (1998). Phenotypic diversity of Pseudoalteromonas citrea from different marine habitats and emendation of the description. Int J Syst Bacteriol 48, 247-256.

Ivanova, E. P., Zhukova, N. V., Svetashev, V. I., Gorshkova, N. M., Kurilenko, V. V., Frolova, G. M. \& Mikhailov, V. V. (2000). Evaluation of phospholipid and fatty acid compositions as chemotaxonomic markers of Alteromonas-like proteobacteria. Curr Microbiol 41, 341-345.

Ivanova, E. P., Gorshkova, N. M., Mikhailov, V. V. \& 7 other authors (2002). The Microbiological Aspect of Radioecological Situation in the Chazhma Bay (Japan Sea/East Sea). 1. Number and Taxonomic Diversity of Sea Saprophitic Bacteria in the Water and Bottom Sediments of the Bay. Vladivostok: Pasific Oceanological Institute FEBRAS.

Ivanova, E. P., Sawabe, T., Zhukova, N. V. \& 8 other authors (2003). Occurrence and diversity of mesophilic Shewanella strains isolated from the North-West Pacific Ocean. Syst Appl Microbiol 26, 293-301.

Marmur, J. (1961). A procedure for the isolation of deoxyribonucleic acid from microorganisms. J Mol Biol 3, 208-218.

Marmur, J. \& Doty, P. (1962). Determination of the base composition of deoxyribonucleic acid from its thermal denaturation temperature. J Mol Biol 5, 109-118.

Melcher, R. J., Apitz, S. E. \& Hemmingsen, B. B. (2002). Impact of irradiation and polycyclic aromatic hydrocarbon spiking on microbial populations in marine sediment for future aging and biodegradability studies. Appl Environ Microbiol 68, 2858-2868.

Moule, A. L. \& Wilkinson, S. G. (1987). Polar lipids, fatty acids and isoprenoid quinones of Alteromonas putrefaciens (Shewanella putrefaciens). Syst Appl Microbiol 9, 192-198.

Nguyen, B. H., Denner, E. B. M., Dang, T. C. H., Wanner, G. \& Stan-Lotter, H. (1999). Marinobacter aquaeolei sp. nov., a halophilic bacterium isolated from a Vietnamese oil-producing well. Int J Syst Bacteriol 49, 367-375.

Perrière, G. \& Gouy, M. (1996). WWW-Query: an on-line retrieval system for biological sequence banks. Biochimie 78, 364-369.

Rontani, J.-F., Bonin, P. C. \& Volkman, J. K. (1999). Production of wax esters during aerobic growth of marine bacteria on isoprenoid compounds. Appl Environ Microbiol 65, 221-230. 
Sasaki, T., Uchida, N. A., Uchida, H., Takasuka, N., Kamiya, H., Endo, Y., Tanaka, M., Hayashi, T. \& Shimizu, Y. (1985). Antitumor activity of aqueous extracts of marine animals. J Pharmacobio-Dyn $\mathbf{8}$, 969-974.

Smibert, R. M. \& Krieg, N. R. (1994). Phenotypic characterization. In Methods for General and Molecular Bacteriology, pp. 607-655. Edited by P. Gerhardt, R. G. E. Murray, W. A. Wood \& N. R. Krieg. Washington, DC: American Society for Microbiology.

Spröer, C., Lang, E., Hobeck, P., Burghardt, J., Stackebrandt, E. \& Tindall, B. J. (1998). Transfer of Pseudomonas nautica to Marinobacter hydrocarbonoclasticus. Int J Syst Bacteriol 48, 1445-1448.
Svetashev, V. I., Vysotskii, M. V., Ivanova, E. P. \& Mikhailov, V. V. (1995). Cellular fatty acid of Alteromonas species. Syst Appl Microbiol 18, 37-43.

Wayne, L. G., Brenner, D. J., Colwell, R. R. \& 9 other authors (1987). International Committee on Systematic Bacteriology. Report of the ad hoc committee on reconciliation of approaches to bacterial systematics. Int J Syst Bacteriol 37, 463-464.

Yoon, J.-H., Shin, D.-Y., Kim, I.-G., Kang, K. H. \& Park, Y.-H. (2003). Marinobacter litoralis sp. nov., a moderately halophilic bacterium isolated from sea water from the East Sea in Korea. Int J Syst Evol Microbiol 53, 563-568. 